\title{
Facial Diplegia-Complication or Manifestation of SARS-CoV-2 Infection? A Case Report and Systemic Literature Review
}

\author{
Anna K. Szewczyk ${ }^{1, * \mathbb{D}}$, Urszula Skrobas ${ }^{1}$, Anna Jamroz-Wiśniewska ${ }^{1}$, Krystyna Mitosek-Szewczyk ${ }^{2}$ \\ and Konrad Rejdak ${ }^{1}$ (D) \\ 1 Department of Neurology, Medical University of Lublin, ul. Jaczewskiego 8, 20-954 Lublin, Poland; \\ skrobas.urszula@gmail.com (U.S.); annajamrozwisniewska@umlub.pl (A.J.-W.); krejdak@yahoo.com (K.R.) \\ 2 Department of Child Neurology, Medical University of Lublin, ul. Profesora Antoniego Gębali 6, \\ 20-093 Lublin, Poland; krystyna.mitosek@gmail.com \\ * Correspondence: szewczyk.anna1@gmail.com
}

check for updates

Citation: Szewczyk, A.K.; Skrobas, U.; Jamroz-Wiśniewska, A.; Mitosek-Szewczyk, K.; Rejdak, K. Facial Diplegia-Complication or Manifestation of SARS-CoV-2 Infection? A Case Report and Systemic Literature Review. Healthcare 2021, 9, 1492. https:// doi.org/10.3390/healthcare9111492

Academic Editors: Pierpaolo Di Micco and Anna Annunziata

Received: 11 September 2021

Accepted: 28 October 2021

Published: 2 November 2021

Publisher's Note: MDPI stays neutral with regard to jurisdictional claims in published maps and institutional affiliations.

Copyright: (C) 2021 by the authors. Licensee MDPI, Basel, Switzerland. This article is an open access article distributed under the terms and conditions of the Creative Commons Attribution (CC BY) license (https:// creativecommons.org/licenses/by/ $4.0 /)$.

\begin{abstract}
Since the outbreak of the new coronavirus, healthcare systems around the world have witnessed not only COVID-19 symptoms but also long-term complications of the aforementioned, including neurological problems. We report a clinical case of an adult patient with bilateral facial nerve palsy and progressive ascending paresis of the limbs after contracting the novel coronavirus (COVID-19). Additionally, the systematic review aimed to identify and summarize specific clinical features, outcomes and complications of the studies focusing on bilateral facial diplegia as a sequela of COVID-19 infection. The total number of analyzed patients was 15. Only one patient was diagnosed with isolated bilateral palsy; the rest had Guillain-Barré Syndrome (GBS). With one exception, all the presented cases had favorable outcomes, with facial palsy recovery from slight to almost complete. In patients with a confirmed COVID-19 diagnosis, bilateral facial palsy may be an isolated symptom as well as a variant of GBS. Symptoms of cranial nerve damage during a COVID-19 infection may explain the appearance of facial nerve damage. In order to clarify the spectrum of neurological manifestations and a causal relation between SARS-CoV-2, COVID-19 vaccination and neurological symptoms, direct attention towards the study of this virus is crucial. It seems reasonable to recognize human coronavirus as another potential GBS trigger.
\end{abstract}

Keywords: COVID-19; SARS-CoV-2; Guillain-Barré Syndrome; peripheral nervous system disease; peripheral facial nerve palsy; Bell's palsy; COVID-19 vaccination

\section{Introduction}

Since the outbreak of the new coronavirus, healthcare systems around the world have witnessed not only COVID-19 symptoms but also long-term complications of the aforementioned. New phenomenon might be overviewed or misdiagnosed due to its novelty or lack of knowledge about the connection to previous severe acute respiratory syndrome coronavirus 2 (SARS-CoV-2) infection, which might have serious consequences including death. There is a need to share knowledge and increase awareness among health care professionals for better management of the patients.

The first reported patient with SARS-CoV-2 in Wuhan, China was reported in December 2019 [1]. The coronavirus family is a group of single-stranded RNA viruses causing respiratory and intestinal infections in the host [2]. In humans, asymptomatic to severe pneumonia leading to death can be observed, as well as fever, cough and myalgia. However, atypical presentation of the disease is not uncommon [3].

Neurological manifestation related to SARS-CoV-2 and other coronaviruses depends on the exact location of the lesion, and their symptoms range from mild to severe. Among peripheral nervous system (PNS) alterations, neuralgia, olfactory and gustatory disorders 
are mentioned. Assessing the changes in the central nervous system (CNS), symptoms such as headache, dizziness, altered consciousness and ischemic or hemorrhagic stroke were observed. Acute inflammation of the CNS (brain, spinal cord and meninges) and PNS were also repeatedly reported $[4,5]$.

\section{Case Report}

A 70-year-old Caucasian male, a proper diction teacher with a medical history of hypertension and stable heart disease, was admitted to our neurological department in November 2020 with acute symmetric progressive ascending paresis of the limbs, impaired sensation and bilateral facial nerve palsy. One month earlier (on 20 October 2020) he was treated at home for suspected SARS-CoV-2 infection without serious complications. The infection manifested itself through fever, gastrointestinal symptoms, headaches and severe pain in the thoracic spine. Three weeks later, the patient had an antibody blood test for SARS-CoV-2 with immunoglobulin $\mathrm{M}(\mathrm{IgM})$ rate at 4.18 (negative result $<1.00$ ) and immunoglobulin $\mathrm{G}(\mathrm{IgG})$ rate at 5.69 (negative result $<1.4)$. Seven days after the disease laboratory confirmation, he came to the GP because of paraesthesia of the distal parts of the limbs and burning of the tongue. A diagnosis of ulcers (aphthae) in the mouth and sensory disturbances due to changes in the cervical and lumbar spine were made. Then, two days later, bilateral paresis of the facial nerve appeared, and he was thus transported from the private neurological praxis by ambulance to our neurology department.

The systemic examination was normal. In the neurological examination the patient presented the following: complete lower motor neuron facial weakness bilaterally, swallowing difficulties, jaw dropping and dysarthria, symmetrical flaccid quadriparesis, absent deep tendon reflexes and sensory disturbances from the thoracic spinal nerve 6 (T6) downwards. The patient complained of a lack of facial expressions and diplopia. Then, due to diaphragm and intercostal muscles paralysis, respiratory disorders of the "compression of the iron rim" type appeared. Brain computed tomography (CT) and magnetic resonance imaging (MRI) were performed without any acute pathological finding. In a thoracic MRI (scope of the study T6-L2) examination, due to striped, subtle contrast enhancement at T12-L1 level on the anterior and dorsal surface of the conus medullaris and the roots of the cauda equina, suspicion arose of Guillain-Barré Syndrome. A lumbar puncture was performed, and the CSF picture revealed normal glucose and cell count with $98 \mathrm{mg} / \mathrm{dL}$ protein level, albumin level at $56.8 \mathrm{mg} / \mathrm{dL}$ and positive oligoclonal bands type IV indicative of damage to the blood-brain barrier. Other laboratory tests were within normal range. A nerve conduction study showed sensorimotor polyneuropathy of a demyelinating-axonal character. The patient received intravenous treatment with immunoglobulins at a dose of $2 \mathrm{~g}$ per kilogram body weight; the course of treatment was uneventful and there was gradual improvement. For further recovery, the patient was transferred to the rehabilitation department.

\section{Materials and Methods}

We report a clinical case of patient with acute symmetric progressive ascending paresis of the limbs and bilateral facial nerve palsy after COVID-19 infection. The primary outcome of literature analysis was to identify and summarize specific clinical features and outcomes in SARS-CoV-2 patients complicated by bilateral facial diplegia. Our review focuses on the disease entities that lead to the emergence of bilateral facial diplegia, their likely underestimation and the impact of SARS-CoV-2 infection and COVID-19 vaccinations on their appearance. To identify appropriate literature, a systematic literature search was conducted based on the PRISMA guidelines [6]. The electronic databases PubMed and Google Scholar were searched for all adult ( $\geq 18$ years) clinical case or case series descriptions or original articles about COVID-19 associated with bilateral facial nerve palsy, published before 30 June 2021. The studies were published in English, French or Polish. The following keywords or MeSH including all commonly used abbreviations of these terms were used: "bilateral facial nerve palsy", "facial diplegia", "bilateral facial nerve palsy", "COVID-19", "SARS-CoV-2", "Guillain-Barré Syndrome", "acute inflammatory 
demyelinating polyneuropathy". For this analysis, we included only clinical studies containing neurological manifestations associated with a COVID-19/SARS-CoV-2 infection. Studies concerning other human coronaviruses or duplicating the cases already mentioned, as well as studies with unconfirmed COVID-19 cases and unilateral facial palsy, were excluded. The search, based on the titles and abstracts of all reports identified through electronic databases, was conducted by two reviewers independently to identify the studies matching the assumed criteria. In case of uncertainty, the full text of the article was obtained and discussed. At the time of writing, we found 14 cases of bilateral facial nerve palsy combined with SARS-CoV-2 infection, which are summarized in Table 1. Two reports for which only abstracts were available were nevertheless included due to meeting the criteria. The results of the statistical analysis are expressed as mean \pm standard deviation. The authors found no review reports about the relationship between bilateral facial palsy and COVID-19 infection.

\section{Results}

This study reported a patient with progressive neurological manifestations in the form of ascending paresis of the limbs and impaired sensation that were initially misdiagnosed. The onset of the neurological symptoms appeared one month after COVID-19 infection, confirmed by the presence of IgG to SARS-CoV-2 in the patient's blood. It was found that $100 \%$ patients reached positive virus-specific IgG after approximately 17-19 days after first symptoms [7].

Fourteen clinical cases were included in this systemic review, with a total of 15 analyzed patients, including the above clinical case. The age of the patients ranged from 20 to 70 years old, the average age was $46.13 \pm 14.61$ and the group was predominantly male $(66.7 \%)$. The time elapsed between first symptoms of infection and admission to hospital due to neurological signs ranged from 2 days to 6 weeks with an average of $18.36 \pm 10.82$ days. Most cases (9/14) had a time lapse between 10 and 21 days. Of the available data, three patients had no symptoms of COVID-19 infection prior to admission, while four patients had a positive RT-PCR SARS-CoV-2 test result. Out of 15 described patients, only one had no albumin-cytological dissociation (ACD) in CSF results and was diagnosed with isolated bilateral facial palsy (BFP) in the context of otherwise asymptomatic COVID-19. Among the other patients, four presented only bilateral facial paresis with no other deviations in the neurological examination. In 5 of the 15 cases, brain MRI showed bilateral contrast enhancement of the facial nerves. Neurophysiological studies results were available for 10 out of 15 patients. The most common finding was demyelinating polyneuropathy. In the treatment, the following were used: intravenous immunoglobulins (IVIG) in $60.00 \%(9 / 15)$ of patients, corticosteroids in $33.33 \%(5 / 15)$ and plasmapheresis in $6.67 \%$ (one case). Data are missing in one case. Fourteen out of fifteen cases reported an improvement from slight to almost complete; however, one patient died from severe autonomic dysfunction (Table 1). 
Table 1. Summary of clinical findings and diagnostic investigations of bilateral facial nerve palsy combined with SARS-CoV-2 infection.

\begin{tabular}{|c|c|c|c|c|c|c|c|c|c|c|}
\hline No. & Article & Sex & Age & $\begin{array}{c}\text { Previous COVID-19 } \\
\text { Symptoms } \\
\end{array}$ & $\begin{array}{c}\text { Time between } \\
\text { Events }\end{array}$ & Symptoms during Admission & CSF & MRI & $\begin{array}{c}\text { Neurophysiological } \\
\text { Studies }\end{array}$ & $\begin{array}{c}\text { Treatment and } \\
\text { Outcome }\end{array}$ \\
\hline 1. & $\begin{array}{l}\text { A. Cabrera-Muras } \\
\text { et al. [8] }\end{array}$ & M & 20 & $\begin{array}{l}\text { odynophagia, fever, } \\
\text { asthenia }\end{array}$ & 2 weeks & $\begin{array}{c}\text {-bilateral facial paresis } \\
\text {-positive NPS RT-PCR } \\
\text { SARS-CoV-2 test result } \\
\text {-Positive Epstein-Barr virus } \\
\text { infection test }\end{array}$ & $\begin{array}{c}\text {-ACD, } \\
\text {-Negative results for } \\
\text { SARS-CoV-2 and other } \\
\text { viruses } \\
\text {-Negative antiganglioside } \\
\text { antibodies (IgM and IgG) } \\
\text { in serum and CSF } \\
\end{array}$ & $\begin{array}{l}\text { Brain: diagnosis of } \\
\text { bilateral facial } \\
\text { neuritis }\end{array}$ & $\begin{array}{c}\text { a severe } \\
\text { neuropathy of the } \\
\text { facial nerve } \\
\text { bilaterally, with } \\
\text { active denervation }\end{array}$ & $\begin{array}{l}\text {-corticosteroids, } \\
\text {-almost complete } \\
\text { facial palsy } \\
\text { recovery after } \\
3 \text { weeks }\end{array}$ \\
\hline 2. & M. Khaja et al. [9] & M & 44 & Asymptomatic & No data & $\begin{array}{l}\text {-Bilateral complete lower } \\
\text { motor neuron facial weakness, } \\
\text {-Positive NPS RT-PCR } \\
\text { SARS-CoV-2 test result }\end{array}$ & $\begin{array}{c}\text {-ACD, } \\
\text {-Negative results for } \\
\text { SARS-CoV-2 and other } \\
\text { viruses }\end{array}$ & Brain: N & No data & $\begin{array}{l}\text {-IVIG, } \\
\text {-slow } \\
\text { improvement }\end{array}$ \\
\hline 3. & $\begin{array}{l}\text { A. Sancho-Saldaña } \\
\text { et al. [10] }\end{array}$ & $\mathrm{F}$ & 56 & $\begin{array}{l}\text { fever, dry cough and } \\
\text { shortness of breath, } \\
\text { positive NPS RT-PCR } \\
\text { SARS-CoV-2 test result }\end{array}$ & 2 days & $\begin{array}{c}\text {-low back pain } \\
\text {-progressive proximal limb } \\
\text { weakness with global } \\
\text { areflexia, } \\
\text {-bilateral facial nerve palsy, } \\
\text { oropharyngeal }\end{array}$ & $\begin{array}{c}\text {-ACD, } \\
\text {-Negative results for } \\
\text { SARS-CoV-2 }\end{array}$ & $\begin{array}{l}\text { Spine: brainstem } \\
\text { and cervical } \\
\text { leptomeningeal } \\
\text { enhancement }\end{array}$ & $\begin{array}{l}\text { Demyelinating } \\
\text { neuropathy }\end{array}$ & $\begin{array}{c}\text {-IVIG, } \\
\text {-Gradual } \\
\text { improvement }\end{array}$ \\
\hline 4. & J. Kerstens et al. [11] & $\mathrm{M}$ & 27 & $\begin{array}{c}\text { Asymptomatic } \\
\text { positive NPS RT-PCR } \\
\text { SARS-CoV-2 test result }\end{array}$ & 5 weeks & $\begin{array}{l}\text {-asymmetrical bilateral } \\
\text { peripheral facial palsy }\end{array}$ & Normal & $\begin{array}{l}\text { Brain: bilateral } \\
\text { contrast } \\
\text { enhancement of } \\
\text { the facial nerves }\end{array}$ & $\begin{array}{l}\text { No evidence for } \\
\text { GBS. }\end{array}$ & $\begin{array}{c}\text {-Corticosteroids, } \\
\text {-antiviral } \\
\text { medication, } \\
\text {-almost complete } \\
\text { recovery two } \\
\text { months later }\end{array}$ \\
\hline 5. & G. Toscano et al. [12] & M & 23 & Fever, sore throat & 10 days & $\begin{array}{c}\text {-complete facial palsy, } \\
\text {-generalized areflexia, } \\
\text {-sensory ataxia } \\
\text {-positive NPS RT-PCR } \\
\text { SARS-CoV-2 test result }\end{array}$ & $\begin{array}{c}-\mathrm{ACD}, \\
\text {-Negative results for } \\
\text { SARS-CoV-2 }\end{array}$ & $\begin{array}{l}\text { Brain: bilateral } \\
\text { contrast } \\
\text { enhancement of } \\
\text { the facial nerves } \\
\text { Spine: N }\end{array}$ & $\begin{array}{l}\text { Axonal } \\
\text { sensory-motor } \\
\text { damage }\end{array}$ & $\begin{array}{l}\text {-IVIG, } \\
\text {-mild } \\
\text { improvement }\end{array}$ \\
\hline 6.* & $\begin{array}{l}\text { P. Jain et al., Atypical } \\
\text { Presentation of } \\
\text { Guillain-Barré } \\
\text { Syndrome (GBS) with } \\
\text { Facial Diplegia and } \\
\text { Retained Reflexes } \\
\text { associated with } \\
\text { COVID-19 Infection }\end{array}$ & M & 43 & $\begin{array}{l}\text { flu-like illness with fever, } \\
\text { headache and } \\
\text { generalized body pain, } \\
\text { suspicion of mild } \\
\text { COVID-19 infection }\end{array}$ & 3 weeks & $\begin{array}{c}\text {-bilateral peripheral facial } \\
\text { nerve palsy }\end{array}$ & $\begin{array}{c}\text {-ACD, } \\
\text {-Negative results for } \\
\text { SARS-CoV-2 and other } \\
\text { viruses }\end{array}$ & $\begin{array}{l}\text { Brain: subtle } \\
\text { enhancement of } \\
\text { seventh cranial } \\
\text { nerve }\end{array}$ & No data & $\begin{array}{c}\text {-IVIG, } \\
\text {-Rapid } \\
\text { improvement }\end{array}$ \\
\hline 7.* & $\begin{array}{l}\text { V. Pandya et al., } \\
\text { COVID-19 Associated } \\
\text { Facial Diplegia and } \\
\text { Lower Extremities } \\
\text { Weakness; Subtype of } \\
\text { GBS: A Case Report }\end{array}$ & $\mathrm{F}$ & 48 & Diagnosed COVID-19 & 3 weeks & $\begin{array}{l}\text {-bilateral facial muscles } \\
\text { weakness, } \\
\text {-symmetrical and proximal } \\
\text { lower extremities weakness, } \\
\text {-bilateral loss of deep tendon } \\
\text { reflexes in the lower } \\
\text { extremities }\end{array}$ & $\begin{array}{c}\text {-ACD, } \\
\text {-negative PCR for } \\
\text { common viral and } \\
\text { bacterial pathogens }\end{array}$ & No data & No data & $\begin{array}{l}\text {-IVIG, } \\
\text {-Significant } \\
\text { improvement }\end{array}$ \\
\hline
\end{tabular}


Table 1. Cont.

\begin{tabular}{|c|c|c|c|c|c|c|c|c|c|c|}
\hline No. & Article & Sex & Age & $\begin{array}{c}\text { Previous COVID-19 } \\
\text { Symptoms }\end{array}$ & $\begin{array}{l}\text { Time between } \\
\text { Events }\end{array}$ & Symptoms during Admission & CSF & MRI & $\begin{array}{l}\text { Neurophysiological } \\
\text { Studies }\end{array}$ & $\begin{array}{l}\text { Treatment and } \\
\text { Outcome }\end{array}$ \\
\hline 8. & C. Judge et al. [13] & M & 64 & $\begin{array}{l}\text { cough, fever and chills, } \\
\text { positive RT-PCR } \\
\text { SARS-CoV-2 test result }\end{array}$ & 3 weeks & $\begin{array}{l}\text {-Peripheral bilateral facial } \\
\text { nerve palsy, more pronounced } \\
\text { on the right }\end{array}$ & $\begin{array}{l}\text {-ACD with lymphocytic } \\
\text { pleocytosis } \\
\text {-Tests for different viruses } \\
\text { were negative }\end{array}$ & Brain: N & No data & $\begin{array}{l}\text {-No data, } \\
\text {-Gradual } \\
\text { improvement }\end{array}$ \\
\hline 9. & J. Caamaño et al. [14] & M & 61 & $\begin{array}{l}\text { fever and coughing, } \\
\text { positive NPS RT-PCR } \\
\text { SARS-CoV-2 test result }\end{array}$ & 10 days & $\begin{array}{c}\text {-bilateral facial nerve palsy } \\
\text {-unresponsive blink reflex on } \\
\text { both eyes }\end{array}$ & $\begin{array}{c}-\mathrm{ACD}, \\
\text {-negative RT-PCR for } \\
\text { SARS-CoV-2 }\end{array}$ & Brain: N & No data & $\begin{array}{c}\text {-Corticosteroids, } \\
\text {-barely notable } \\
\text { improvement }\end{array}$ \\
\hline 10. & N. Mackenzie et al. [15] & $\mathrm{F}$ & 39 & $\begin{array}{l}\text { ageusia, anosmia and } \\
\text { intense headache }\end{array}$ & 14 days & $\begin{array}{c}\text {-peripheral facial diplegia, } \\
\text {-generalized quadriparesis } \\
\text { and hyporeflexia, } \\
\text {-positive NPS RT-PCR } \\
\text { SARS-CoV-2 test result }\end{array}$ & $\mathrm{ACD}$ & $\begin{array}{l}\text { Spine: result not } \\
\text { related with the } \\
\text { clinical signs and } \\
\text { symptoms }\end{array}$ & $\begin{array}{l}\text { confirmed the GBS } \\
\text { diagnosis }\end{array}$ & $\begin{array}{c}\text {-Plasmapheresis, } \\
\text {-Corticosteroids, } \\
\text {-Gradual } \\
\text { improvement }\end{array}$ \\
\hline 11. & T. Pelea et al. [16] & $\mathrm{F}$ & 56 & $\begin{array}{l}\text { dry cough, mild fever } \\
\text { and a general weakness, } \\
\text { positive NPS RT-PCR } \\
\text { SARS-CoV-2 test result }\end{array}$ & 7 days & $\begin{array}{l}\text {-gradual progression, paresis } \\
\text { in four limbs, } \\
\text {-absent deep tendon reflexes, } \\
\text {-sensory disturbances } \\
\text {-5 days later: severe } \\
\text { tetraparesis and bilateral } \\
\text { peripheral facial nerve palsy }\end{array}$ & $\begin{array}{c}-\mathrm{ACD}, \\
\text {-negative RT-PCR for } \\
\text { SARS-CoV-2 }\end{array}$ & Spine: $\mathrm{N}$ & $\begin{array}{l}\text { axonal } \\
\text { demyelinating } \\
\text { neuropathy }\end{array}$ & $\begin{array}{l}\text {-IVIG, } \\
\text {-only slight } \\
\text { improvement }\end{array}$ \\
\hline 12. & M. Abolmaali et al. [17] & M & 47 & Dyspnea and cough & 10 days & $\begin{array}{c}\text {-Dysarthria, } \\
\text {-mild muscle weakness and } \\
\text { generalized hyporeflexia } \\
\text {-severe low back pain with } \\
\text { quadriparesis } \\
\text {-areflexia, } \\
\text {-bilateral facial palsy }\end{array}$ & ACD & Brain and spine: $\mathrm{N}$ & $\begin{array}{c}\text { acute } \\
\text { motor-sensory } \\
\text { axonal (AMSAN) } \\
\text { neuropathy }\end{array}$ & $\begin{array}{c}\text {-Corticosteroids, } \\
\text {-died from severe } \\
\text { autonomic } \\
\text { dysfunction }\end{array}$ \\
\hline 13. & J.L. Chan et al. [18] & M & 58 & $\begin{array}{l}\text { Exposed to SARS-CoV-2 } \\
\text { in the workplace, } \\
\text { asymptomatic }\end{array}$ & 20 days & $\begin{array}{c}\text {-complete facial diplegia and } \\
\text { areflexia in the lower } \\
\text { extremities, } \\
\text {-dysarthria } \\
\text {-positive NPS RT-PCR } \\
\text { SARS-CoV-2 test results }\end{array}$ & $\begin{array}{c}\text { ACD, } \\
\text { negative RT-PCR for } \\
\text { SARS-CoV-2 }\end{array}$ & $\begin{array}{l}\text { Brain: bilateral } \\
\text { facial nerve } \\
\text { enhancement }\end{array}$ & $\begin{array}{c}\text { acute } \\
\text { inflammatory } \\
\text { demyelinating } \\
\text { polyneuropathy }\end{array}$ & $\begin{array}{l}\text {-IVIG, } \\
\text {-slight } \\
\text { improvement }\end{array}$ \\
\hline 14. & J. Aasfara et al. [19] & $\mathrm{F}$ & 36 & Diagnosed COVID-19 & 6 weeks & $\begin{array}{c}\text {-reduced tendon reflexes, } \\
\text {-left peripheral facial palsy } \\
\text {-After } 24 \mathrm{~h} \text {, right peripheral } \\
\text { facial palsy and asymmetric } \\
\text { distal numbness } \\
\text {-Blood serology revealed IgG } \\
\text { SARS-CoV-2 antibody }\end{array}$ & $\begin{array}{c}\text { ACD, } \\
\text { PCR for several viruses, } \\
\text { including, SARS-CoV-2, } \\
\text { were negative }\end{array}$ & Brain and spine: $\mathrm{N}$ & $\begin{array}{l}\text { demyelinating } \\
\text { pattern of GBS }\end{array}$ & $\begin{array}{l}\text {-IVIG, } \\
\text {-Gradual } \\
\text { improvement }\end{array}$ \\
\hline
\end{tabular}

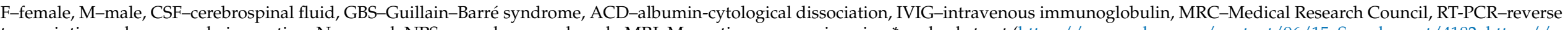

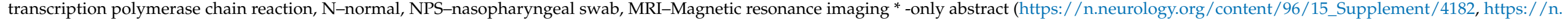
neurology.org/content/96/15_Supplement/4246) (accessed on 30 June 2021). 


\section{Discussion}

The first clinical case of a patient with GBS and SARS-CoV-2 infection was presented in The Lancet Neurology Journal [20]. On 23rd January 2020, a 61 year-old woman, who had returned from Wuhan 4 days earlier, presented fatigue and rapidly progressive weakness in both legs, with no different general symptoms. Over time, the symptoms advanced to areflexia, with sensory disturbances and upper limb involvement. Lymphocytopenia and thrombocytopenia in the blood test and CSF albumin-cytological dissociation were reported in laboratory results. The results of nerve conduction studies supported diagnosis of demyelinating neuropathy and GBS. Treatment with immunoglobulins was applied; nevertheless a few days later, due to infectious symptoms, she tested positive for COVID-19 via RT-PCR testing and was transferred to an isolation room.

Guillain-Barré Syndrome, despite being a rare disease, is diagnosed at any age and is the most common cause of acute flaccid paresis [21]. GBS incidence varies considerably with geographic location, with ranges between 0.4 and 3.25 or 0.6 to 4.0 cases per 100,000 people [22,23]. In children, the incidence rate is lower, approx. 0.69 per 100,000 person per year [24]. Referring to research conducted in Europe, a populationbased study pointed out an incidence rate of 1.2-1.9 per 100,000 people [25]. This disease affects slightly more men than women and appears at around 40 years of age. The underlying cause of the higher incidence of the disease in men is not yet known [26,27]; however, this predominance seems to increase with age [28]. A higher proportion of the pure motor type is observed in younger patients, whilst the sensorimotor type increases with age [29]. Seasonal changes are also described, providing a higher incidence rate in winter compared to in summer $[30,31]$. Perhaps this seasonal variability can be linked with several demographic, immunological or environmental factors, including climatic conditions conducive to seasonal infections, like gastrointestinal and respiratory tract infections [32].

The relationship between COVID-19 and GBS and the resulting symptoms continue to be investigated. The vast majority of studies were published as case reports or series of cases [33-35]. Abu-Rumeileh et al. presented the clinical cases of 73 patients with confirmed COVID-19 history, in which he referred to 52 articles; Sriwastava et al. identified 50 GBS cases from 37 studies, while Finsterer et al. reviewed at least 220 patients from 95 papers at the end of December 2020 [36]. The number of patients experiencing GBS in the context of COVID-19 appears higher than anticipated, though there are still no unequivocal results. The similarity of the demographic results obtained in this review may support SARS-CoV-2 having a role in triggering GBS.

On the one hand, the number of registered GBS cases, while underestimated, has fallen during the COVID-19 pandemic; on the other hand, altered social conduct is observed. Due to changes in social behavior, such as social distancing and the use of personal protective equipment and hygienic procedures, the prevention of infectious diseases, known as triggers of GBS, has increased [37,38]. Recent comments characterizing GBS as occurring in occasional clusters can be found as well [39]. Another study presented results with neither an observed raise in the incidence of GBS in pandemic nor epidemiological evidence that SARS-CoV-2 is a causative factor for GBS [40]. The limited access to the healthcare and risk of co-infection in COVID-19 patients may also distort statistics [37]. Therefore, the exact number of GBS cases in the pandemic is difficult to estimate and long-term observation is still required.

Multiple potential "classical" triggers of GBS have been reported e.g., Campylobacter jejuni (C. jejuni), cytomegalovirus, Epstein-Barr virus, influenza and Zika virus infection, or vaccination. After a bacterial or viral infection, a cross-reaction called molecular mimicry appears, in which antibodies and nerve ending antigens are involved [41,42]. As one of the best-known virulence factors, sialylation of lipo-oligosaccharides (LOS) of the Gramnegative bacterium Campylobacter jejuni is mentioned. Its molecular similarity to ganglioside structures (GM1) on human spinal nerve roots drives immune-mediated nerve damage. As many as one-fourth or one-third of patients after this infection can develop 
GBS [43]. There are several classes of LOS; however, three of them-A, B and C-are isolated from GBS-patient stool. The first is associated with GBS and the second with Miller Fisher syndrome (MFS) [44].

In COVID-19 and neurological damage, three pathogenic pathways are proposed: direct damage, dysregulated inflammatory response and antibody-mediated injury. Freire et al. suggest neuro-invasive ability by disrupting the blood-brain barrier (BBB). Pro-inflammatory cytokines increase BBB permeability and activate glial cells [45] or retrograde axonal transport through the olfactory nerve or the enteric nervous system. Elevated neuroinflammatory parameters in serum and/or CSF have also been described in SARS-CoV-2, as well as cell-mediated immunity in GBS. Antibody-mediated mechanisms seem to be of less importance in the pathogenesis of this viral disease entity [46]. A negative SARS-CoV-2 RT-PCR test in CSF usually suggests against direct viral entry into the CNS; however, falsenegatives might occur in early stages of the disease course [47]. The detection of human coronavirus $(\mathrm{CoV})$ in patients' brains can indicate that the brain may be a long-period viral reservoir without causing neurological symptoms [48]. Moreover, a post-mortem case series did not find an association between the presence of SARS-CoV-2 in the CNS and the severity of neuropathological changes [49]. The penetration of the coronavirus into the nervous system may be related to the spread from peripheral tissues through peripheral nerves to the CNS. The angiotensin converting enzyme 2 (ACE-2) receptor may also have a role in the spread of the virus, because SARS-CoV-2 binds to its enzymatic domain. ACE-2 receptors are exposed on the surface of several cell types (e.g., endothelial, epithelial, but also neuroepithelial and neurons) which may facilitate the entry of the virus into the nervous system. Dysfunction of the olfactory system in the form of hyposmia or anosmia, as the most common symptoms of SARS-CoV-2 infection, is evidence of damage to the cranial nerves. Cranial neuropathies in COVID-19 also appear as ageusia, ocular motor palsies, and trigeminal function impairment [50-52]. Post-infectious symptoms, such as the sensation of a blocked nose or of burning result from the affection of nasal chemesthesis and are mediated via the trigeminal nerve. These findings may suggest a potential route of penetration of SARS-CoV-2 through the intranasal trigeminal nerve endings. Spread of the virus from nasal epithelial cells to the olfactory bulb has also been suggested $[53,54]$. There are reports of the suppression of the olfactory system by the massive calcitonin gene-related peptide (CGRP) release from the overactive trigeminal afferent system. In this context, acquired anosmia may be due to functional connections between the olfactory and trigeminal system, and emerging headaches are associated with vigorous activation of trigeminal afferents [55,56].

Probable aetiology of Bell's palsy is also associated with viral and autoimmune diseases; however, congenital conditions, traumas and idiopathy are also mentioned. Bell's palsy incidence is approximately $15-30$ cases per 100,000 people annually [57] and it affects women and men equally. Among viruses known to have a neurotrophic capacity for peripheral nerves are the following: herpes simplex virus 1 and 2 (HSV-1, HSV-2) and varicella zoster virus (VZV). Thanks to mucocutaneous exposure, they are able to enter the body and remain there in a latent form in multiple ganglia (such as autonomic, cranial or dorsal root) throughout the neuroaxis. Under favorable conditions, they can become reactive in an immunocompetent host. Perhaps the neural dysfunction related to HSV-1 is inducted by the activation of intra-axonal degradation and apoptotic pathways (direct and indirect responses) or, similar to GBS, by a cell-mediated immune response against myelin [58]. Mechanisms leading to the appearance of idiopathic Bell's palsy include the following: inflammatory induced demyelination, ischemia of vasa nervorum and vascular damage. The latter are mentioned among the probable causes of facial nerve ischemia in COVID-19; however, an inflammatory process cannot be ruled out either [59]. Isolated unilateral Bell's palsy in the context of atypical COVID-19 presentation was reported in the literature $[60,61]$ with a delay of about $7-10$ days between infection and the onset of neurological symptoms. In the cross-sectional study carried out on 41 patients with acute 
peripheral facial paralysis as the only symptom, almost one fourth obtained a positive SARS-CoV-2 IgG + IgM test [62].

Bilateral facial weakness is one of the prognostic risk factors contributing to mechanical ventilation in GBS [63]. The mortality rate of GBS varied between studies from $2 \%$ to even $20 \%$ [64]. Mechanical ventilation is needed in more than one fifth of patients due to respiratory failure. Unfortunately, up to $60 \%$ of intubated patients develop major complications in the form of sepsis, pneumonia or pulmonary embolism [65]. Extended follow-up of 12 months after hospitalization reported a post-GBS mortality rate of 3.9\% [66]. COVID-19 infection may also worsen the outcomes of GBS patients. This co-infection contributed to both frequent arterial hypotension and admission to the ICU and worse patient Medical Research Council (MRC) sum scores [67].

Authors are debating increasingly the possible effects of COVID-19 on the onset of peripheral facial nerve palsy. Opinions are divided: Özdemir Ö. [68] in his letter to editors rejects the possibility of coincidental Bell's palsy alongside SARS-CoV-2 infection in the pediatric population. Other studies report that the connection between COVID-19 infection and peripheral facial nerve palsy should be confirmed by further laboratory and post-mortem studies, since the number of patients with Bell's palsy during the pandemic seems to be at the same level compared to previous years [69]; however, the available data differ $[70,71]$. At the same time, Egilmez O. et al. support the hypothesis that the SARSCoV-2 virus can influence the appearance of Bell's palsy symptoms through increasing hypercoagulopathy or direct toxic effect to the nerve [72]. It is also worth emphasizing that the suspicion of SARS-CoV-2 infection 14 days prior to the appearance of facial nerve palsy may be deceptive due to the multiplicity of clinical symptoms of viral infection [73].

Recently, Nasuelli et al. reported a patient who developed four-limb distal paraesthesia, bilateral facial diplegia and postural instability ten days after vaccination with Oxford-AstraZeneca chimpanzee adenovirus vectored vaccine ChAdOx1 nCoV-19 [74]. Perhaps the SARS-CoV-2 antigen(s) or chimpanzee adenovirus adjuvant contained in the vaccination may induce immune mechanisms leading to myelitis [75] or the vaccineassociated autoimmunity of DNA vaccines (ChAdOx1 and Ad26.COV2.S) is connected with cross-reaction between antibodies against the spike protein and peripheral nerve constituents [76]. This pathophysiology still remains unknown and requires further research. For the sake of public health, the clear information on the emergence of post-vaccination complications remains of paramount importance; however, it still remains limited. Available reports suggest a potential small but statistically significant safety concern for GBS following receipt of the Ad26.COV2.S vaccine (Janssen/Johnson \& Johnson). Despite the study limitations, the absolute risk of GBS following this vaccination seems to be extremely small and much lower than the risk of COVID-19 infection [77]. The research conducted in Mexico [78] showed that GBS is infrequent among recipients of the BNT162b2 vaccine (Pfizer-BioNTech). The most cases of GBS emergence after vaccination were related to concomitant factors identified as gastrointestinal infections. This fact may indicate a lack of mechanistic connection between mRNA vaccines and GBS and vaccine safety. Also, in the case-control study, no association was found between the acute facial nerve palsy and recent vaccination with the BNT162b2 vaccine. Unlike the extremely rare reports of facial nerve palsy after vaccination, the administrations for facial nerve palsy seem to remain at a similar level compared to previous years [79].

In order to avoid complications of potential adverse events of COVID-19 vaccination, medical professionals should be aware of symptoms such as peripheral nerve palsy or suggestive of GBS [80]. Nevertheless, the vaccines' benefits appear to outweigh the potential risks of developing either of these complications.

The presence of uncommon characteristics or confounding factors (e.g., pure dysautonomic presentation of GBS [81,82]) can lead to a misdiagnosis, serious health consequences, and even death [83]. For this reason, clinicians should be alerted to the wide spectrum of symptoms occurring in GBS or COVID-19 infection. 
This systemic review has several limitations. The included studies are mostly clinical reports and focus on specific neurological symptoms. The number of reports is limited and the studies are retrospective. Due to the ongoing pandemic, many related studies have not yet been published, which could influence the results. There is also a high risk of cross-infection, which limited the evidence of neurological involvement.

\section{Conclusions}

In patients with a confirmed COVID-19 infection, bilateral facial palsy may be an isolated symptom as well as a variant of Guillain-Barré Syndrome. Except for one patient, the presented cases had favorable outcomes ranging from slight to almost complete recovery from facial palsy. Olfactory and gustatory dysfunctions, as well as the appearance of oculomotor palsies and trigeminal impairment in the course of this viral infection, are evidence of the involvement of the cranial nerves, which would explain also the observed facial nerve damage.

GBS is reported as one of the more common neurological complications of SARSCoV-2, especially since the connection between this disease entity and viral infections has already been proven. It seems reasonable to recognize and include human coronavirus as another GBS potential trigger.

Medical professionals should be aware of potential adverse events of COVID-19 vaccinations, among which Bell's palsy and symptoms suggestive of GBS may appear. Nevertheless, the vaccines' benefits appear to outweigh the potential risks of developing either of these complications.

The current epidemiological situation and extremely frequent neurological complications related to the COVID-19 infection pushed the researchers to a wide analysis of its pathogenic mechanisms and manifestations. The etiopathogenesis is still unknown and requires further research. It appears that, due to negative PCR SARS-CoV-2 results in CSF, immune/cell-mediated reaction against SARS-CoV-2 should be considered rather than direct viral origin pathology; however, a potential route of penetration through the intranasal trigeminal nerve endings is also suggested. In order to clarify the spectrum of neurological manifestations and a causal relationship between SARS-CoV-2, COVID-19 vaccination and neurological symptoms, direct attention towards the study of this virus is crucial.

Author Contributions: Conceptualization, A.K.S., U.S. and A.J.-W.; methodology, A.K.S.; formal analysis, A.K.S.; investigation, A.K.S. and K.M.-S.; resources, A.K.S.; data curation, A.J.-W.; writingoriginal draft preparation, A.K.S. and U.S.; writing-review and editing, A.K.S. and A. J-W.; supervision, K.M.-S. and K.R.; project administration, A.K.S.; funding acquisition, K.R. All authors have read and agreed to the published version of the manuscript.

Funding: This research received no external funding.

Institutional Review Board Statement: The study was conducted according to the guidelines of the Declaration of Helsinki, and approved by the Ethics Committee of Medical University of Lublin, Poland.

Informed Consent Statement: Informed consent was obtained from all subjects involved in the study.

Conflicts of Interest: The authors declare no conflict of interest.

\section{References}

1. Li, Q.; Guan, X.; Wu, P.; Wang, X.; Zhou, L.; Tong, Y.; Ren, R.; Leung, K.S.M.; Lau, E.H.Y.; Wong, J.Y.; et al. Early Transmission Dynamics in Wuhan, China, of Novel Coronavirus-Infected Pneumonia. N. Engl. J. Med. 2020, 382, 1199-1207. [CrossRef]

2. Machhi, J.; Herskovitz, J.; Senan, A.M.; Dutta, D.; Nath, B.; Oleynikov, M.D.; Blomberg, W.R.; Meigs, D.D.; Hasan, M.; Patel, M.; et al. The Natural History, Pathobiology, and Clinical Manifestations of SARS-CoV-2 Infections. J. Neuroimmune Pharmacol. 2020, 15, 359-386. [CrossRef] [PubMed]

3. Wu, D.; Wu, T.; Liu, Q.; Yang, Z. The SARS-CoV-2 outbreak: What we know. Int. J. Infect. Dis. 2020, 94, 44-48. [CrossRef]

4. Wang, L.; Shen, Y.; Li, M.; Chuang, H.; Ye, Y.; Zhao, H.; Wang, H. Clinical manifestations and evidence of neurological involvement in 2019 novel coronavirus SARS-CoV-2: A systematic review and meta-analysis. J. Neurol. 2020, 267, 2777-2789. [CrossRef] 
5. Correia, A.O.; Feitosa, P.W.G.; de Sousa Moreira, J.L.; Nogueira, S.Á.R.; Fonseca, R.B.; Nobre, M.E.P. Neurological manifestations of COVID-19 and other coronaviruses: A systematic review. Neurol. Psychiatry Brain Res. 2020, 37, 27-32. [CrossRef] [PubMed]

6. Page, M.J.; McKenzie, J.E.; Bossuyt, P.M.; Boutron, I.; Hoffmann, T.C.; Mulrow, C.D.; Shamseer, L.; Tetzlaff, J.M.; Akl, E.A.; Brennan, S.E.; et al. The PRISMA 2020 statement: An updated guideline for reporting systematic reviews. BMJ 2021, 372, n71. [CrossRef]

7. Long, Q.X.; Liu, B.Z.; Deng, H.J.; Wu, G.C.; Deng, K.; Chen, Y.K.; Liao, P.; Qiu, J.F.; Lin, Y.; Cai, X.F.; et al. Antibody responses to SARS-CoV-2 in patients with COVID-19. Nat. Med. 2020, 26, 845-848. [CrossRef]

8. Cabrera Muras, A.; Carmona-Abellán, M.M.; Collía Fernández, A.; Uterga Valiente, J.M.; Antón Méndez, L.; García-Moncó, J.C. Bilateral facial nerve palsy associated with COVID-19 and Epstein-Barr virus co-infection. Eur. J. Neurol. 2021, 28, 358-360. [CrossRef] [PubMed]

9. Khaja, M.; Roa Gomez, G.P.; Santana, Y.; Hernandez, N.; Haider, A.; Lara, J.L.P.; Elkin, R. A 44-year-old hispanic man with loss of taste and bilateral facial weakness diagnosed with Guillain-Barré Syndrome and Bell's Palsy associated with SARS-CoV-2 infection treated with intravenous immunoglobulin. Am. J. Case Rep. 2020, 21, 1-6. [CrossRef] [PubMed]

10. Sancho-Saldaña, A.; Lambea-Gil, Á.; Capablo Liesa, J.L.; Barrena Caballo, M.R.; Garay, M.H.; Celada, D.R.; Serrano-Ponz, M. Guillain-Barré Syndrome associated with leptomeningeal enhancement following SARS-CoV-2 infection. Clin. Med. 2020, 20, E93-E94. [CrossRef] [PubMed]

11. Kerstens, J.; Deschuytere, L.; Schotsmans, K.; Maréchal, E. Bilateral peripheral facial palsy following asymptomatic COVID-19 infection: A case report. Acta Neurol. Belg. 2021, 121, 815-816. [CrossRef] [PubMed]

12. Toscano, G.; Palmerini, F.; Ravaglia, S.; Ruiz, L.; Invernizzi, P.; Cuzzoni, M.G.; Franciotta, D.; Baldanti, F.; Daturi, R.; Postorino, P.; et al. Guillain-Barré Syndrome Associated with SARS-CoV-2. N. Engl. J. Med. 2020, 382, 2574-2576. [CrossRef]

13. Judge, C.; Moheb, N.; Castro Apolo, R.; Dupont, J.L.; Gessner, M.L.; Yacoub, H.A. Facial Diplegia as a Rare Late Neurologic Manifestation of SARS-CoV-2 Infection. J. Neurol. Res. 2020, 10, 235-236. [CrossRef]

14. Juliao Caamaño, D.S.; Alonso Beato, R. Facial diplegia, a possible atypical variant of Guillain-Barré Syndrome as a rare neurological complication of SARS-CoV-2. J. Clin. Neurosci. 2020, 77, 230-232. [CrossRef] [PubMed]

15. Mackenzie, N.; Lopez-Coronel, E.; Dau, A.; Maloof, D.; Mattar, S.; Garcia, J.T.; Fontecha, B.; Lanata, C.M.; Guillen-burgos, H.F. Concomitant Guillain-Barre syndrome with COVID-19: A case report. BMC Neurol. 2021, 21, 1-4. [CrossRef]

16. Pelea, T.; Reuter, U.; Schmidt, C.; Laubinger, R.; Siegmund, R.; Walther, B.W. SARS-CoV-2 associated Guillain-Barré syndrome. J. Neurol. 2021, 268, 1191-1194. [CrossRef]

17. Abolmaali, M.; Heidari, M.; Zeinali, M.; Moghaddam, P.; Ramezani Ghamsari, M.; Jamshidi Makiani, M.; Mirzaasgari, Z. Guillain-Barré syndrome as a parainfectious manifestation of SARS-CoV-2 infection: A case series. J. Clin. Neurosci. 2021, 83, 119-122. [CrossRef] [PubMed]

18. Chan, J.L.; Ebadi, H.; Sarna, J.R. Guillain-Barré Syndrome with Facial Diplegia Related to SARS-CoV-2 Infection. Can. J. Neurol. Sci. 2020, 47, 852-854. [CrossRef]

19. Aasfara, J.; Hajjij, A.; Bensouda, H.; Ouhabi, H.; Benariba, F. A unique association of bifacial weakness, paresthesia and vestibulocochlear neuritis as post-COVID-19 manifestation in pregnant women: A case report. Pan. Afr. Med. J. 2021, 38, 1-5. [CrossRef]

20. Zhao, H.; Shen, D.; Zhou, H.; Liu, J.; Chen, S. Guillain-Barré Syndrome associated with SARS-CoV-2 infection: Causality or coincidence? Lancet Neurol. 2020, 19, 383-384. [CrossRef]

21. Shahrizaila, N.; Lehmann, H.C.; Kuwabara, S. Guillain-Barré Syndrome. Lancet 2021, 397, 1214-1228. [CrossRef]

22. Wijdicks, E.F.M.; Klein, C.J. Guillain-Barré Syndrome. Mayo Clin. Proc. 2017, 92, 467-479. [CrossRef] [PubMed]

23. Dimachkie, M.M.; Barohn, R.J. Guillain-Barré Syndrome and variants. Neurol. Clin. 2013, 31, 491-510. [CrossRef]

24. Levison, L.S.; Thomsen, R.W.; Markvardsen, L.K.; Christensen, D.H.; Sindrup, S.H.; Andersen, H. Pediatric Guillain-Barré Syndrome in a 30-Year Nationwide Cohort. Pediatr. Neurol. 2020, 107, 57-63. [CrossRef]

25. Chiò, A.; Cocito, D.; Leone, M.; Giordana, M.T.; Mora, G.; Mutani, R.; Calvo, A.; Di Vito, N.; Vercellino, M.; Bertolotto, A.; et al. Guillain-Barré Syndrome: A prospective, population-based incidence and outcome survey. Neurology 2003, 60, 1146-1150. [CrossRef]

26. Sejvar, J.J.; Baughman, A.L.; Wise, M.; Morgan, O.W. Population incidence of Guillain-Barré Syndrome: A systematic review and meta-analysis. Neuroepidemiology 2011, 36, 123-133. [CrossRef]

27. McGrogan, A.; Madle, G.C.; Seaman, H.E.; De Vries, C.S. The epidemiology of Guillain-Barré Syndrome worldwide: A systematic literature review. Neuroepidemiology 2009, 32, 150-163. [CrossRef]

28. Al-Hakem, H.; Sindrup, S.H.; Andersen, H.; de la Cour, C.D.; Lassen, L.L.; van den Berg, B.; Jacobs, B.C.; Harbo, T. Guillain-Barré syndrome in Denmark: A population-based study on epidemiology, diagnosis and clinical severity. J. Neurol. 2019, 266, 440-449. [CrossRef]

29. Rabie, M.; Nevo, Y. Childhood acute and chronic immune-mediated polyradiculoneuropathies. Eur. J. Paediatr. Neurol. 2009, 13, 209-218. [CrossRef]

30. Delannoy, A.; Rudant, J.; Chaignot, C.; Bolgert, F.; Mikaeloff, Y.; Weill, A. Guillain-Barré syndrome in France: A nationwide epidemiological analysis based on hospital discharge data (2008-2013). J. Peripher. Nerv. Syst. 2017, 22, 51-58. [CrossRef] [PubMed] 
31. Giordano, A.; Vabanesi, M.; Dalla Costa, G.; Cerri, F.; Comi, G.; Martinelli, V.; Fazio, R. Assessing seasonal dynamics of Guillain-Barré Syndrome with search engine query data. Neurol. Sci. 2019, 40, 1015-1018. [CrossRef] [PubMed]

32. Webb, A.J.S.; Brain, S.A.E.; Wood, R.; Rinaldi, S.; Turner, M.R. Seasonal variation in Guillain-Barré Syndrome: A systematic review, meta-analysis and Oxfordshire cohort study. J. Neurol. Neurosurg. Psychiatry 2015, 86, 1196-1201. [CrossRef] [PubMed]

33. De Sanctis, P.; Doneddu, P.E.; Viganò, L.; Selmi, C.; Nobile-Orazio, E. Guillain-Barré syndrome associated with SARS-CoV-2 infection. A systematic review. Eur. J. Neurol. 2020, 27, 2361-2370. [CrossRef] [PubMed]

34. Abu-Rumeileh, S.; Abdelhak, A.; Foschi, M.; Tumani, H.; Otto, M. Guillain-Barré Syndrome Spectrum Associated with COVID-19: An Up-To-Date Systematic Review of 73 Cases; Springer: Berlin/Heidelberg, Germany, 2020; ISBN 0123456789.

35. Sriwastava, S.; Kataria, S.; Tandon, M.; Patel, J.; Patel, R.; Jowkar, A.; Daimee, M.; Bernitsas, E.; Jaiswal, P.; Lisak, R.P. Guillain Barré Syndrome and its variants as a manifestation of COVID-19: A systemic review of case report and case series. J. Neurol. Sci. 2021, 420, 117263. [CrossRef]

36. Finsterer, J.; Scorza, F.A. Guillain-Barre syndrome in 220 patients with COVID-19. Egypt. J. Neurol. Psychiatry Neurosurg. 2021, 57, 55. [CrossRef]

37. Keddie, S.; Pakpoor, J.; Mousele, C.; Pipis, M.; Machado, P.M.; Foster, M.; Record, C.J.; Keh, R.Y.S.; Fehmi, J.; Paterson, R.W.; et al. Epidemiological and cohort study finds no association between COVID-19 and Guillain-Barré Syndrome. Brain 2020, 144, 682-693. [CrossRef] [PubMed]

38. Reszke, R.; Szepietowska, M.; Krajewski, P.K.; Matusiak, Ł.; Białynicki-Birula, R.; Szepietowski, J.C. Face mask usage among young polish people during the COVID-19 epidemic-An evolving scenario. Healthcare 2021, 9, 638. [CrossRef]

39. Tatu, L.; Nono, S.; Grácio, S.; Koçer, S. Guillain-Barré syndrome in the COVID-19 era: Another occasional cluster? J. Neurol. 2021, 268, 1198-1200. [CrossRef]

40. Rinaldi, S. Coronavirus Disease 2019 and the Risk of Guillain-Barré Syndrome. Ann. Neurol. 2021, 89, 846. [CrossRef]

41. Hao, Y.; Wang, W.; Jacobs, B.C.; Qiao, B.; Chen, M.; Liu, D.; Feng, X.; Wang, Y. Antecedent infections in Guillain-Barré Syndrome: A single-center, prospective study. Ann. Clin. Transl. Neurol. 2019, 6, 2510-2517. [CrossRef]

42. Vellozzi, C.; Iqbal, S.; Broder, K. Guillain-barré syndrome, influenza, and influenza vaccination: The epidemiologic evidence. Clin. Infect. Dis. 2014, 58, 1149-1155. [CrossRef] [PubMed]

43. Yuki, N.; Susuki, K.; Koga, M.; Nishimoto, Y.; Odaka, M.; Hirata, K.; Taguchi, K.; Miyatake, T.; Furukawa, K.; Kobata, T.; et al. Carbohydrate mimicry between human ganglioside GM1 and Campylobacter jejuni lipooligosaccharide causes Guillain-Barré Syndrome. Proc. Natl. Acad. Sci. USA 2004, 101, 11404-11409. [CrossRef]

44. Heikema, A.P.; Islam, Z.; Horst-Kreft, D.; Huizinga, R.; Jacobs, B.C.; Wagenaar, J.A.; Poly, F.; Guerry, P.; van Belkum, A.; Parker, C.T.; et al. Campylobacter jejuni capsular genotypes are related to Guillain-Barré Syndrome. Clin. Microbiol. Infect. 2015, 21, 852.e1-852.e9. [CrossRef] [PubMed]

45. Najjar, S.; Pahlajani, S.; De Sanctis, V.; Stern, J.N.H.; Najjar, A.; Chong, D. Neurovascular Unit Dysfunction and Blood-Brain Barrier Hyperpermeability Contribute to Schizophrenia Neurobiology: A Theoretical Integration of Clinical and Experimental Evidence. Front. Psychiatry 2017, 8, 83. [CrossRef]

46. Freire, M.; Andrade, A.; Sopeña, B.; Lopez-Rodriguez, M.; Varela, P.; Cacabelos, P.; Esteban, H.; González-Quintela, A. Guillain Barré syndrome associated with COVID-19-lessons learned about its pathogenesis during the first year of the pandemic, a systematic review. Autoimmun. Rev. 2020, 20, 102875. [CrossRef]

47. Najjar, S.; Najjar, A.; Chong, D.J.; Pramanik, B.K.; Kirsch, C.; Kuzniecky, R.I.; Pacia, S.V.; Azhar, S. Central nervous system complications associated with SARS-CoV-2 infection: Integrative concepts of pathophysiology and case reports. J. Neuroinflammation 2020, 17, 1-14. [CrossRef]

48. Matias-Guiu, J.; Gomez-Pinedo, U.; Montero-Escribano, P.; Gomez-Iglesias, P.; Porta-Etessam, J.; Matias-Guiu, J. ¿Es esperable que haya cuadros neurológicos por la pandemia por SARS-CoV-2? Neurología 2020, 35, 170-175. [CrossRef] [PubMed]

49. Matschke, J.; Lütgehetmann, M.; Hagel, C.; Sperhake, J.P.; Schröder, A.S.; Edler, C.; Mushumba, H.; Fitzek, A.; Allweiss, L.; Dandri, M.; et al. Neuropathology of patients with COVID-19 in Germany: A post-mortem case series. Lancet Neurol. 2020, 19, 919-929. [CrossRef]

50. Reza-Zaldívar, E.E.; Hernández-Sapiéns, M.A.; Minjarez, B.; Gómez-Pinedo, U.; Márquez-Aguirre, A.L.; Mateos-Díaz, J.C.; Matias-Guiu, J.; Canales-Aguirre, A.A. Infection Mechanism of SARS-CoV-2 and Its Implication on the Nervous System. Front. Immunol. 2021, 11, 621735. [CrossRef]

51. Costello, F.; Dalakas, M.C. Cranial neuropathies and COVID-19: Neurotropism and autoimmunity. Neurology 2020, 95, 195-196. [CrossRef] [PubMed]

52. Lechien, J.R.; Chiesa-Estomba, C.M.; De Siati, D.R.; Horoi, M.; Le Bon, S.D.; Rodriguez, A.; Dequanter, D.; Blecic, S.; El Afia, F.; Distinguin, L.; et al. Olfactory and gustatory dysfunctions as a clinical presentation of mild-to-moderate forms of the coronavirus disease (COVID-19): A multicenter European study. Eur. Arch. Oto-Rhino-Laryngol. 2020, 277, 2251-2261. [CrossRef]

53. Ferreli, F.; Di Bari, M.; Gaino, F.; Albanese, A.; Politi, L.S.; Spriano, G.; Mercante, G. Trigeminal features in COVID-19 patients with smell impairment. Int. Forum Allergy Rhinol. 2021, 11, 1253-1255. [CrossRef]

54. Otte, M.S.; Bork, M.L.; Zimmermann, P.H.; Klußmann, J.P.; Lüers, J.C. Patients with COVID-19-associated olfactory impairment also show impaired trigeminal function. Auris Nasus Larynx 2021. [CrossRef] [PubMed] 
55. Messlinger, K.; Neuhuber, W.; May, A. Activation of the Trigeminal System as a Likely Target of SARS-CoV-2 May Contribute to Anosmia in COVID-19. Cephalalgia 2021. Available online: https://journals.sagepub.com/doi/full/10.1177/03331024211036665 (accessed on 2 November 2021). [CrossRef]

56. Frasnelli, J.; Schuster, B.; Hummel, T. Interactions between olfaction and the trigeminal system: What can be learned from olfactory loss. Cereb. Cortex 2007, 17, 2268-2275. [CrossRef]

57. Greco, A.; Gallo, A.; Fusconi, M.; Marinelli, C.; Macri, G.F.; de Vincentiis, M. Bell's palsy and autoimmunity. Autoimmun. Rev. 2012, 12, 323-328. [CrossRef]

58. Eviston, T.J.; Croxson, G.R.; Kennedy, P.G.E.; Hadlock, T.; Krishnan, A.V. Bell's palsy: Aetiology, clinical features and multidisciplinary care. J. Neurol. Neurosurg. Psychiatry 2015, 86, 1356-1361. [CrossRef] [PubMed]

59. Lima, M.A.; Silva, M.T.T.; Soares, C.N.; Coutinho, R.; Oliveira, H.S.; Afonso, L.; Espíndola, O.; Leite, A.C.; Araujo, A. Peripheral facial nerve palsy associated with COVID-19. J. Neurovirol. 2020, 26, 941-944. [CrossRef] [PubMed]

60. Derollez, C.; Alberto, T.; Leroi, I.; Mackowiak, M.A.; Chen, Y. Facial nerve palsy: An atypical clinical manifestation of COVID-19 infection in a family cluster. Eur. J. Neurol. 2020, 27, 2670-2672. [CrossRef]

61. Taouihar, S.; Bouabdallaoui, A.; Aabdi, M.; Kaouini, A.; El Aidouni, G.; Merbouh, M.; Zaid, I.; Bkiyar, H.; Housni, B. Peripheral facial paralysis as the only symptom revealing SARS-CoV 2 infection: Case report. Ann. Med. Surg. 2021, 68, 102550. [CrossRef]

62. Islamoglu, Y.; Celik, B.; Kiris, M. Facial paralysis as the only symptom of COVID-19: A prospective study. Am. J. Otolaryngol. 2021, 42, 2-5. [CrossRef] [PubMed]

63. Lawn, N.D.; Fletcher, D.D.; Henderson, R.D.; Wolter, T.D.; Wijdicks, E.F.M. Anticipating mechanical ventilation in Guillain-Barré Syndrome. Arch. Neurol. 2001, 58, 893-898. [CrossRef] [PubMed]

64. Fletcher, D.D.; Lawn, N.D.; Wolter, T.D.; Wijdicks, E.F.M. Long-term outcome in patients with Guillain-Barre syndrome requiring mechanical ventilation. Neurology 2000, 54, 2311-2315. [CrossRef] [PubMed]

65. Durand, M.C.; Porcher, R.; Orlikowski, D.; Aboab, J.; Devaux, C.; Clair, B.; Annane, D.; Gaillard, J.L.; Lofaso, F.; Raphael, J.C.; et al. Clinical and electrophysiological predictors of respiratory failure in Guillain-Barré Syndrome: A prospective study. Lancet Neurol. 2006, 5, 1021-1028. [CrossRef]

66. Van Den Berg, B.; Bunschoten, C.; van Doorn, P.A.; Jacobs, B.C. Mortality in Guillain-Barré Syndrome. Neurology 2013, 80, 1650-1654. [CrossRef]

67. Filosto, M.; Cotti Piccinelli, S.; Gazzina, S.; Foresti, C.; Frigeni, B.; Servalli, M.C.; Sessa, M.; Cosentino, G.; Marchioni, E.; Ravaglia, S.; et al. Guillain-Barré Syndrome and COVID-19: An observational multicentre study from two Italian hotspot regions. J. Neurol. Neurosurg. Psychiatry 2020, 92, 751-756. [CrossRef]

68. Özdemir, Ö. Bell's palsy development during SARS-CoV-2 infection. Brain Dev. 2021, 43, 889. [CrossRef]

69. Mutlu, A.; Kalcioglu, M.T.; Gunduz, A.Y.; Bakici, B.; Yilmaz, U.; Cag, Y. Does the SARS-CoV-2 pandemic really increase the frequency of peripheral facial palsy? Am. J. Otolaryngol. 2021, 42, 103032. [CrossRef]

70. Zammit, M.; Markey, A.; Webb, C. A rise in facial nerve palsies during the coronavirus disease 2019 pandemic. J. Laryngol. Otol. 2020, 134, 905-908. [CrossRef]

71. Codeluppi, L.; Venturelli, F.; Rossi, J.; Fasano, A.; Toschi, G.; Pacillo, F.; Cavallieri, F.; Giorgi Rossi, P.; Valzania, F. Facial palsy during the COVID-19 pandemic. Brain Behav. 2021, 11, e01939. [CrossRef]

72. Egilmez, O.K.; Gündoğan, M.E.; Yılmaz, M.S.; Güven, M. Can COVID-19 Cause Peripheral Facial Nerve Palsy? SN Compr. Clin. Med. 2021, 3, 1707-1713. [CrossRef] [PubMed]

73. Finsterer, J.; Scorza, F.A.; Scorza, C.A.; Fiorini, A.C. Attributing increased prevalence of facial palsy to SARS-CoV-2 requires evidence. Brain Behav. 2021, 11, e01996. [CrossRef]

74. Nasuelli, N.A.; De Marchi, F.; Cecchin, M.; De Paoli, I.; Onorato, S.; Pettinaroli, R.; Savoini, G.; Godi, L. A case of acute demyelinating polyradiculoneuropathy with bilateral facial palsy after ChAdOx1 nCoV-19 vaccine. Neurol. Sci. 2021, 42, 4747-4749. [CrossRef]

75. Román, G.C.; Gracia, F.; Torres, A.; Palacios, A.; Gracia, K.; Harris, D. Acute Transverse Myelitis (ATM): Clinical Review of 43 Patients with COVID-19-Associated ATM and 3 Post-Vaccination ATM Serious Adverse Events with the ChAdOx1 nCoV-19 Vaccine (AZD1222). Front. Immunol. 2021, 12, 879. [CrossRef] [PubMed]

76. Min, Y.G.; Ju, W.; Ha, Y.E.; Ban, J.J.; Lee, S.A.; Sung, J.J.; Shin, J.Y. Sensory Guillain-Barre syndrome following the ChAdOx1 nCov-19 vaccine: Report of two cases and review of literature. J. Neuroimmunol. 2021, 359, 577691. [CrossRef]

77. Woo, E.; Mba-Jonas, A.; Dimova, R.; Alimchandani, M.; Zinderman, C.; Nair, N. Association of Receipt of the Ad26.COV2.S COVID-19 Vaccine With Presumptive Guillain-Barré Syndrome, February-July 2021. JAMA 2021, 326, 1606-1613. [CrossRef] [PubMed]

78. García-Grimshaw, M.; Michel-Chávez, A.; Vera-Zertuche, J.M.; Galnares-Olalde, J.A.; Hernández-Vanegas, L.E.; FigueroaCucurachi, M.; Paredes-Ceballos, O.; Reyes-Terán, G.; Carbajal-Sandoval, G.; Ceballos-Liceaga, S.E.; et al. Guillain-Barré Syndrome is infrequent among recipients of the BNT162b2 mRNA COVID-19 vaccine. Clin. Immunol. 2021, 230, 1-4. [CrossRef]

79. Shemer, A.; Pras, E.; Einan-Lifshitz, A.; Dubinsky-Pertzov, B.; Hecht, I. Association of COVID-19 Vaccination and Facial Nerve Palsy: A Case-Control Study. JAMA Otolaryngol. Head Neck Surg. 2021, 147, 739-743. [CrossRef]

80. Leung, C. Guillain-Barre syndrome should be monitored upon mass vaccination against SARS-CoV-2. Hum. Vaccines Immunother. 2021, 17, 2957-2958. [CrossRef] 
81. Biassoni, E.; Assini, A.; Gandoglia, I.; Benedetti, L.; Boni, S.; Pontali, E.; Feasi, M.; Gandolfo, F.; Del, M. The importance of thinking about Guillain-Barré syndrome during the COVID-19 pandemic: A case with pure dysautonomic presentation. J. Neurovirol. 2021, 27, 662-665. [CrossRef]

82. Sciacca, G.; Nicoletti, A.; Fermo, S.L.; Mostile, G.; Giliberto, C.; Zappia, M. Looks can be deceiving: Three cases of neurological diseases mimicking Guillain-Barrè syndrome. Neurol. Sci. 2015, 37, 541-545. [CrossRef] [PubMed]

83. McGillicuddy, D.C.; Walker, O.; Shapiro, N.I.; Edlow, J.A. Guillain-Barré Syndrome in the emergency department. Ann. Emerg. Med. 2006, 47, 390-393. [CrossRef] [PubMed] 